Running title: New bioenergetic perspective of hake (Merluccius merluccius L.) reproductive ecology.

\title{
New bioenergetic perspective of European hake (Merluccius merluccius L.)
} reproductive ecology.

R. Domínguez-Petit and F. Saborido-Rey.

\author{
Institute of Marine Research (CSIC), Eduardo Cabello, 6; 36208 Vigo (Spain)
}

Author to whom correspondence should be addressed. Tel:+34 986231 930; Fax:+34 986292 762; e-mail: rosario@iim.csic.es 
Running title: New bioenergetic perspective of hake (Merluccius merluccius L.) reproductive ecology.

8

\section{ABSTRACT}

In spite of the economic and ecologic importance of hake and the depletion of the European stocks, studies about this specie, especially about its reproductive potential, are almost nonexistent. In the present work relationship between gonad development and female's physiological condition and energy reserves has been studied. Gonadosomatic index (GSI) was significantly but not strongly related to condition factor $(\mathrm{K})$ and not significantly related to hepatosomatic index (HSI), whereas gonad energy content was positively related to liver and muscle energy content. On the other hand, it was observed that both, number of developing oocytes (NDO) and batch fecundity (BF), were significantly related to length and gutted weight. Besides, NDO was related to HSI and Total fish energy reserves, while BF was significantly related to liver energy density. Multiple regression models were constructed using maternal attributes as variables. $27 \%$ of NDO and $57 \%$ of $\mathrm{BF}$ variability was explained by these models. Results suggest that European hake egg production depends more on energy intake during spawning season and growth capacity than in energy reserves accumulated several months before spawning season begins.

Key words: Merluccius merluccius, energy investment, fecundity, reproductive strategy.

\section{INTRODUCTION}

European hake (Merluccius merluccius) is one of the most important economic resources for Spanish fleet. For assessment purposes, the International Council for the Exploration of the Sea (ICES) considers two stocks for European hake in the North-east Atlantic (Northern and Southern Stock) based on the presence of a geographical barrier (Cape Breton Canyon) and the observation of two spawning areas: in the Northwest coast of Iberian Peninsula and from the French coast to Celtic Sea. 
Running title: New bioenergetic perspective of hake (Merluccius merluccius L.) reproductive ecology.

In general, it is accepted by most authors that European hake fecundity is indeterminate, i.e., oocytes continuously recruit to the secondary growth stage during the spawning season. This type of fecundity is associated with asynchronous development of the oocytes, which is the same as saying that oocytes of all stages of development are present without dominant cohorts, except when hydration occurs producing a dramatic increase of the size of oocytes that are going to be released, and creating an hiatus between advanced yolked oocytes and hydrated oocytes. Hake is a serial or batch spawner (Murua et al., 1998), and in Galician Shelf shows a protracted spawning season which may well extend to the whole year, at the population level, with a main peak of activity in

Maternal attributes and condition affect fish maturity (Marteinsdottir and Begg, 2002; Morgan and Lilly, 2006; Grift et al., 2007), fecundity and egg production (Kjesbu et al., 1991; Rijnsdorp et al., 1991; Lambert and Dutil, 2000; Marshall et al. 2006) and offspring viability (Brooks et al., 1997; Heyer et al., 2001; Berkley et al., 2004), thus condition is affecting stock reproductive potential and should be included in assessment models (Morgan, 2008). Fish condition can be assessed based on different measures: morpho-physiological indices based on length-weight ratio or organ-body weight ratios (condition factor, hepatosomatic, gonadosomatic, gut and muscle-somatic indices) that offer a proxy of energy reserves of fish and physiological-biochemical indices (proximate 
Running title: New bioenergetic perspective of hake (Merluccius merluccius L.) reproductive ecology.

composition, RNA/DNA content, energy content, etc.) that describe fish condition more precisely

57 (Shulman and Love, 1999).

In spite of the economic and ecologic importance of hake and the depletion of the European stocks (ICES, 2007), studies about this specie, especially about its reproductive potential, are almost nonexistent. The indeterminate reproductive style and the difficulties to keep hake in captivity make its study problematic. Assessment of commercial fish stocks is based on forecasting stock productivity (recruitment and spawning stock biomass) in order to estimate the maximum sustainable yield. To improve stock productivity estimates, deep knowledge of fish reproductive ecology is needed. This work springs from the necessity of improving our knowledge of the reproductive dynamics of European hake. It is focused from a bioenergetic point of view, studying not only the effect of morpho-physiological indices on oocyte development dynamic as traditionally but also physiological-biochemical indices impact. The main goal is to determine what maternal factors are affecting egg production dynamic; with this aim it was studied:

- Relationship between morpho-physiological and physiological-biochemical indices.

- Energetic dynamic and relationships between gonad, liver and muscle during spawning season.

- Relationship between egg production indices (number of developing oocytes and batch fecundity) and maternal condition indices (morpho-physiological and physiological-biochemical indices). 
Running title: New bioenergetic perspective of hake (Merluccius merluccius L.) reproductive ecology.

A number of 69 sampling surveys were carried out from November 2002 to November 2004. Sampling area covered the Galician shelf, although highest sampling intensity was on the West coast (Figure 1). Samples were stratified by length class.

Within the main sampling period, from January 2003 to November 2004, a total of 2,012 female hake were collected. Table I shows distribution of samples by date and length class. From every specimen the following data were taken: length $(\mathrm{cm})$, total weight, gutted weight, sex, macroscopic and microscopic ovary developmental stage and gonad and liver weight. Fifty female hakes were selected for bioenergetics analyses depending on their size and microscopic maturity stage. One ovary, liver and muscle slice from the latter area of the dorsal fin, were removed from each of them. These samples were frozen at $-22^{\circ} \mathrm{C}$ until their analysis in the laboratory. Lipid, protein, glycogen and water content were estimated in the three tissues and energy density, defined as $\mathrm{kJ}$ per gram of dry tissue, according to Domínguez-Petit et al. (2009). Specific energy contents of each biochemical compound, according to Kleiber (1975), were: lipids=39.5 kJ/g dry weight; proteins $=23.6 \mathrm{~kJ} / \mathrm{g}$ dry weight and glycogen $=17.1 \mathrm{~kJ} / \mathrm{g}$ dry weight.

Energy density of each tissue $(\mathrm{kJ} / \mathrm{g})$ was estimated based on their proximate composition and specific energy content of lipids, proteins and glycogen. Liver total energy was obtained multiplying liver energy density by liver weight. Total muscle energy was estimated similarly using carcass weight. Total fish energy reserve was the result of adding total liver and muscle energy.

Three general indices were calculated in order to have an approximation of maturity and condition stage of females: gonadosomatic index (GSI), hepatosomatic index (HSI) and condition factor (K). These indexes are defined by the following equations: 
Running title: New bioenergetic perspective of hake (Merluccius merluccius L.) reproductive ecology.

102

103

104

105

106

107

(i) $G S I=\frac{\text { gonad } W}{\text { gutted } W} \cdot 100$

(ii) $H S I=\frac{\text { liver } W}{\text { gutted } W} \cdot 100$

(iii) $K=\frac{\text { gutted } W}{\text { length }} \cdot 100$

Where $\mathrm{W}$ is an expression of weight.

According to bibliography (Murua and Motos, 1998; 2006), hake has indeterminate fecundity, so it is not possible to estimate any fixed potential fecundity. Because of this, it was decided to use the new term Number of Developing Oocytes (NDO) that refers to number of oocytes that are maturing in the ovary in a specific moment of spawning season. NDO and batch fecundity (BF) were estimated using combined Gravimetric Method and Image Analysis (Domínguez-Petit, 2007). With this aim, ovary was weighed in the laboratory with a precision of $0.01 \mathrm{~g}$; subsamples of about 40 mg were taken from the ovary central area, oocytes were separated from connective tissue using a washing process (modified from Lowerre-Barbieri and Barbieri, 1993). Oocytes were counted and measured and number of oocytes recruited to the maturing pool was then estimated using the equation:

(iv) $N D O=\frac{O W \cdot N_{S}}{S W}$

where $\mathrm{OW}$ is the ovaries weight after fixation, $\mathrm{SW}$ the subsample weight and $\mathrm{N}_{\mathrm{s}}$ the number of developing oocytes in the subsample. 
Running title: New bioenergetic perspective of hake (Merluccius merluccius L.) reproductive ecology.

\section{Statistical ANALYSIS}

Simple regression analysis was used, not only to establish existing relationship between general condition indexes, but also to check if there was any relationship between tissues' energy density. Relationships of NDO and BF with length, gutted weight, HSI and K and fish energy storage (liver and muscle energy density and total fish energy) were analysed. Besides, multiple regression analysis was carried out to check influences of maternal attributes (morpho-physiological and physiological-biochemical indices) on NDO and BF variability. Colinearity between variables was studied and only uncorrelated variables were included in multiple regression models.

\section{RESULTS}

First of all, relationship between GSI, HSI and K was analyzed in order to clarify if gonad size depends on female's condition. Attending to results, it was observed that GSI was significantly related to $\mathrm{K}\left(\mathrm{r}^{2}=0.049, \mathrm{p}<0.01\right)$ but not to HSI $(\mathrm{p}>0.05$; Fig 2$)$. Anyway the fitness to the linear model was not good to consider that both variables, GSI and K, were strongly correlated.

On the other hand, when relationship between energy density in each analyzed tissue (gonad, liver and muscle) was checked, it was detected that gonad energy density increased significantly with both liver and muscle energy density $\left(r^{2}=0.174, p<0.01 ; r^{2}=0.082, p<0.05\right.$, respectively; Fig 3$)$, although determination coefficient remained being low, so the explanatory power is low. Neither liver nor muscle energy density was related to female length, gutted weigth or liver weight, i.e. larger females does not accumulate more energy per gram of liver or muscle. 
Running title: New bioenergetic perspective of hake (Merluccius merluccius L.) reproductive ecology.

$\mathrm{NDO}$ as well as BF are important parameters to estimate reproductive potential of species with indeterminate fecundity. In the present study NDO fluctuated between 1,133 and 4,020,407 developing oocytes per female and BF between 271 and 835,230 hydrated oocytes per female with mean values of 747,158 developing oocytes and 114,593 hydrated oocytes per female respectively. Table II shows determination coefficient, correlation coefficient and p-values of relationships between NDO and BF and female's length, gutted weight, HSI, condition factor K and energy density content in liver and muscle as well as total fish energy. It was detected that NDO was positive related with length, gutted weight, HSI and total fish energy. In any case, determination coefficients were rather low for all variables $\left(\mathrm{r}^{2}<0.5\right)$. Gutted weight showed the best correlation to NDO ( $r=0.637)$, but any of them has enough explanatory power to be considered as a proxy of NDO.

Regarding BF, positive relationships were observed with length and gutted weight whereas negative relationship was detected with liver energy density that means females with lower levels of energy density in liver may produce larger batches. Females may have used more energy to produce relatively larger batches. Nevertheless, percentage of BF variation explained for each variable independently considered was around $45 \%$, so they have not enough prediction power to be used independently as proxies of BF. Anyway, in the case of BF, biochemical composition, and consequently liver and muscle energy density were analyzed only in 9 females (those with hydrated ovaries) so results must be interpreted with caution.

In addition, multiple regression was carried out to study the impact of different maternal attributes on NDO or BF considered together in a single model. For NDO, variables considered in the multiple regression analysis were gutted weight, HSI, K and liver and muscle energy density, and 
Running title: New bioenergetic perspective of hake (Merluccius merluccius L.) reproductive ecology.

those included in the model were, in this order, gutted weigth, liver energy density and HSI. Explained variability was 27\% (Fig 4a). For BF, biochemical indices were not considered because of the low number of observations, so variables considered for the analysis were gutted weight, liver weight, HSI and K. In this case all variables were included in the model and explained variability was $56.5 \%$ (Fig $4 \mathrm{~b}$ ). The order of inclusion was gutted weight, $\mathrm{K}$, liver weight and HSI and $49 \%$ of total BF variability was explained by gutted weight, so inclusion of other variables did not improve significantly BF predictions.

\section{DISCUSSION}

Stock Reproductive Potential (SRP) depends on population factors like genetic pool, size/age at maturity, or size/age structure of the stock and parental condition (Lambert et al., 2000; O’Brien et al., 2003; Saborido-Rey et al., 2004; Scott et al., 2005). In European hake from Galician Shelf, energy dynamics and NDO-maternal attributes relationships considered in conjunction may improve our understanding of its SRP. According to results, both NDO as well as BF of hake from Galician Shelf increased with length and gutted weight of female that means larger females recruited more occytes in each pulse (NDO) and released more eggs in each batch (BF) what would mean higher egg production and higher possibilities of offspring survivorship. Reproductive potential of population depends on spawning stock length/age structure that may affects to other reproductive parameters of hake like size at first maturity (Domínguez et al., 2008). NDO increases with total fish energy, but not ultimately with energy density (i.e. energy accumulated per gram of tissue) what means that mobilization of oocytes depends more on female size than in relative energy reserves. However, gonad development and body reserves are related as they fluctuate concurrently, i.e. when energy in muscle and liver increases, also does in gonad, meaning that 
Running title: New bioenergetic perspective of hake (Merluccius merluccius L.) reproductive ecology.

gonad develops when there is a energy intake surplus, but not at the expenses of accumulated energy like in cold water species (Marshall et al., 1999; Lambert and Dutil, 2000), since in that case energy density in liver and muscle will decrease as gonad further develops. In Gasterosteus aculeatus has been observed that fecundity is determined partially by female weight at the beginning of spawning season but once it has started to spawn, the number of batches produced depends on food intake (Wootton. 1985). On the other hand, Millner et al. (1991) hypothesized that Solea solea used energy surplus to growth and increase condition and that results indirectly in an increase of egg production, but there is not a direct relationship between energy reserves and fecundity.

In cold waters, food availability is higher during late spring-autumn, while in winter, when spawning usually takes place for most of the commercial species, food is scarce, consequently vitellogenesis relies on stored energy in months previous to oocytes development. On the contrary, our results suggest that hake continues feeding during the breeding season. The number of eggs released in each batch (i.e. BF) from NDO pool depends on female size. Apparently, oocyte recruitment rate, i.e. number of oocytes recruiting from primary to secondary growth stage is also larger in larger females. In consequence, larger females show NDO and BF values 5-7 times higher than smaller females. This indicates that larger females very likely produce more eggs and hence realized fecundity is higher in larger females. This seems to be in accordance with other gadoids like Atlantic cod, where larger females have longer spawning periods and produce more and larger batches than smaller ones (Chambers and Walwood, 1996; Bleil and Oeberst, 1998; Marteinsdottir and Begg, 2002). However, in European hake the NDOs recruited from the primary growth oocytes stock must be modulated by the capacity to capture energy from feeding during spawning season. Larger females have certain advantages for obtaining food, they can predate on wider range of prey- 
Running title: New bioenergetic perspective of hake (Merluccius merluccius L.) reproductive ecology.

size, their swimming rate is higher than small females one, are less sensitive to predation risk, etc. (Mittlebach, 1981; Townsend and Winfield, 1985; Ryer, 1988), that means larger females have more capacity to obtain energy than samller ones, so they can recruit more oocytes and more rapidly, resulting in higher total egg production. It can also be hypothesised that the oocyte development rates depend on female size or short-term energy reserves (feeding capacity), but more studies are needed to clarify relationships between maternal condition and attributes like oocyte growth dynamics and egg production in this species (Domínguez-Petit, 2007). Attending to this, SRP variability in hake from Galician Shelf is highly affected by environmental conditions that determined food availability and female's metabolic expenditure.

Although it is known that egg size is an important determinant of egg survival, and hence of larval survival too (Hislop, 1988; Brooks et al., 1997), no data on egg size has been analysed in the present work. Saborido-Rey et al. (2003) observed in Atlantic cod that differences in the size and specific gravity of eggs affect their buoyancy, and consequently may affect the probability of survival. At the same time, the size of eggs depends on their composition, which is function of female condition (Marteinsdottir and Begg, 2002). Relationship between hydrated oocyte diameter as proxy of egg size, and different condition indices are analyzed in Mehault et al. (In press. This issue) studying the impact of female condition on offspring survivorship and future recruitment.

In summary, in hake during the breeding season part of the assimilated energy is allocated to gamete production in such manner that the dependence on energy reserves is reduced. This explains why energy content in liver and muscle do not decrease as ovary develops. On the contrary, increasing female capacity to assimilate energy during the breeding season is reflected in higher energy content in body tissue, including ovary, having as consequence a higher number of 
Running title: New bioenergetic perspective of hake (Merluccius merluccius L.) reproductive ecology.

developing oocytes at any given moment. Assimilated energy depends on a number of factors, as food availability, temperature but also increased body size will likely reduce the risk of being predated and also improve feeding opportunities (Saborido-Rey and Kjesbu, in press). As energy allocated to reproduction increases with female size (Kjesbu et al., 1998), also in hake NDO, batch fecundity and very likely the number of batches produced in the season increases also with size; however, fecundity will be regulated by feeding activity during breeding season instead of by accumulated energy, i.e. a very different strategy of the cold water species.

\section{AKNOWLEDGMENTS}

This work was funded by the European Commission within the $5^{\text {th }}$ Framework Program "Quality of Life and Management of Living Resources" within the RASER project, "Reproduction and Stock Evaluation for Recovery" (Q5RS-2002-01825). Data from Galicia Government Project XUGA$40201 B 98$ have been also used. We would like to thank Dolores Domínguez, Alexandre Alonso, Mariña Fabeiro and Sonia Rábade for technical support.

\section{REFERENCES}

- Alonso-Fernández, A., Domínguez-Petit, R., Bao, M., Rivas, C., Saborido-Rey, F. 2009. Spawning pattern and reproductive strategy of female pouting Trisopterus luscus (Gadidae), on the Galician shelf of north-western Spain. Aquat. Liv. Res. 21(4), 383-393.

- Berkeley, S.A., Chapman, C., Sogard, S.M. 2004. Maternal age as a determinant of larval growth and survival in a marine fish, Sebastes melanops. Ecol. 85(5), 1258-1264. 
Running title: New bioenergetic perspective of hake (Merluccius merluccius L.) reproductive ecology.

- Brooks, S.; Tyler, C.R., Sumpter, J.P. 1997. Egg quality in fish: what makes a good egg? Rev. Fish Biol. Fisher. 7(4), 387-416.

- Bleil, M., Oeberst, R. 1998. The spawning of cod (Gadus morhua morhua) under controlled condition of captivity, quantity and quality of spawned eggs. ICES. C.M. 1998/DD:3. $27 \mathrm{pp}$.

- Chambers, C.R., K.G. Walwood. 1996. Maternal and seasonal difference in egg sizes and spawning characteristics of captive Atlantic cod, Gadus morhua. Can. J. Fish. Aquat. Sci. 53, 1986-2003.

- Domínguez-Petit, R. 2007. Study of reproductive potential of Merluccius merluccius in the Galician Shelf. Doctoral Thesis. University of Vigo (Spain). DOI: 10261/4377.

- Domínguez, R., Korta, M., Saborido-Rey, F., Murua, H., Sainza, M., Piñeiro, C. 2008. Analysis of the influence of stock structure and environmental changes in size at maturity for both European hake Atlantic populations. J. Mar. Sys. 71, 260-278.

- Domínguez-Petit, R., Saborido-Rey, F., Medina, I. 2009. Changes of proximate composition, energy storage and condition of European hake (Merlucciusmerluccius, L. 1758) through spawning season. Fish. Res. DOI: 10.1016/j.fishres.2009.03.007

- Grift, R.E., Heino, M., Rijnsdorp, A.D., Kraak, S.B.M., Dieckmann, U. 2007. Three-dimensional maturation reaction norms for North Sea plaice. Mar. Ecol. Prog. Ser. 334, 213-224.

- Heyer, C.J.; Miller, T.J.; Binkowski, F.P.; Caldarone, E.M., Rice, J.A. 2001. Maternal effects as a recruitment mechanism in Lake Michigan yellow perch (Perca flavescens). Can. J. Fish. Aquat. Sci. 58, 1477-1487.

- Hislop, J.R.G. 1988. The influence of maternal length and age on the size and weight of the eggs and the relative fecundity of the haddock, Melanogrammus aeglefinus, in British waters. J. Fish Biol. 32(6), 923-930. 
Running title: New bioenergetic perspective of hake (Merluccius merluccius L.) reproductive ecology.

- Hislop, J.R.G., Probb, A.P., Gauld, J.A. 1978. Observations on effects of feeding level on growth and reproduction in haddock, Melanogrammus aeglefinus (L.) in captivity. J. Fish. Biol. 13 (1), 85-98.

- ICES. 2003. Report of the Study Group on growth, maturity and condition in stock projections. ICES CM 2003/D:01. Ref. ACFM, C, G, H, WGMG . 95pp.

- ICES. 2007. Report of the Working Group on the assessment of Southern Shelf Stocks of hake, monk and megrim. ICES CM 2007/ACFM:21. 706pp.

- Kjesbu, O.S. 1989. The spawning activity of cod, Gadus morhua L. J. Fish Biol. 34(2), 195-206.

- Kjesbu, O.S., Klungsøyr, J., Kryvi, H., Witthames, P.R., Greer Walker, M. 1991. Fecundity, atresia, and egg size of captive Atlantic cod (Gadus morhua) in relation to proximate body composition. Can. J. Fish. Aquat. Sci. 48, 2333-2343.

- Kjesbu, O.S., Witthames, P.R., Solemdal, P., Greer Walker, M. 1998. Temporal variations in the fecundity of Arcto-Norwegian cod (Gadus morhua) in response to natural changes in food and temperature. J. Sea Res. 40, 303-321.

- Kleiber, M. 1975. The fire of life: an introduction to animal energetics. Robert E. Krieger Publishing Company, New York. 453 pp.

- Lambert, Y., Dutil, J.D. 2000. Energetic consequences of reproduction in Atlantic cod (Gadus morhua) in relation to spawning level of somatic energy reserves. Can. J. Fish. Aquat. Sci. 57, 815-825.

- Lambert, Y., Dutil, J., Ouellet, P. 2000. Nutritional condition and reproductive success in wild fish populations. 6th International Symposium on the Reproductive Physiology of Fish. Bergen (Norway), 4-9 Jul 1999. pp: 77-84. 
Running title: New bioenergetic perspective of hake (Merluccius merluccius L.) reproductive ecology.

314 - Lloris, D., Matallanas, J., Oliver, P. 2005. Hakes of the World (Family Merluciidae): an Annotated and Illustrated Catalogue of Hake Species Known to Date. FAO Species Catalogue for Fisheries Purposes 2, 69 pp.

- Lowerre-Barbieri, S.K., Barbieri, L.R. 1993. A new method of oocyte separation and preservation for fish reproduction studies. Fish. Bull. 91(1), 165-170.

- Marshall, C.T., Needle, C.L., Thorsen, A., Kjesbu, O.S., Yagarina, N.A. 2006. Systematic bias in estimates of reproductive potential of an Atlantic cod (Gadus morhua) stock: implications for stock-recruit theory and management. Can. J. Fish. Aquat. Sci. 63, 980-994.

- Marteinsdottir, G., Begg, G.A. 2002. Essential relationships incorporating the influence of age, size and condition on variables required for estimation of reproductive potential in Atlantic cod Gadus morhua. Mar. Ecol. Prog. Ser. 235, 235-256.

- Mehault, S., Domínguez-Petit, R., Cerviño, S., Saborido-Rey, F. In press. Total Egg Production and implications for management of the Southern stock of European hake. Fish. Res.

- Millner, R., Whiting, C., Greer Walker, M., Witthames, P. 1991. Growth increment, condition and fecundity in sole (Solea solea (L.)) from the North Sea and eastern English Channel. Nether. J. Sea Res. 27(3/4), 433-439.

- Mittelbach, G.G. 1981. Foraging efficiency and body size: a study of optimal diet and habitat use by bluegills. Ecology. 62(5), 1370-1386.

- Morgan, M.J. 2008. Integrating reproductive biology into scientific advice for fisheries management. J. Northw. Atl. Fish. Sci. 41, 37-51.

- Morgan, M. J., Lilly, G.R. 2006. The impact of condition on reproduction in Flemish Cap cod. J. Northw. Atl. Fish. Sci. 37, 81-86. 
Running title: New bioenergetic perspective of hake (Merluccius merluccius L.) reproductive ecology.

- Murua H., Motos L., Lucio, P. 1998. Reproductive modality and batch fecundity of the European hake (Merluccius merluccius) in the Bay of Biscay. CalCOFI Reports. 39:196-203.

- Murua H., Motos L. 2006. Reproductive strategy and spawning activity of the European hake Merluccius merluccius (L.) in the Bay of Biscay. J. Fish Biol. 69, 1288-1303.

- O’Brien, L.; Rago, P.J., Berrien, P., Lough, G. 2003. Incorporating early-life history parameters in the estimation of the stock-recruit relationship of Georges Bank Atlantic cod (Gadus morhua). J. Northw. Atl. Fish. Sci. 33, 191-205.

- Rijnsdorp, A.D., Daan, N., Van Beek, F.A., Heesen, H.J.L. 1991. Reproductive variability in North Sea plaice, sole and cod. ICES Journal. 47, 352-375.

- Ryer, C.H. 1988. Pipefish foraging: effects of fish size, prey size and altered habitat complexity. Mar. Ecol. Prog. Ser. 48, 37-45.

- Saborido-Rey, F., Kjesbu, O.S. In press. In: Dieckmann, U., Godø, O.R., Heino, M., Mork, M. (Eds.), Growth and maturation dynamics. In Fisheries-Induced Adaptive Changes. Cambridge University Press.

- Saborido-Rey, F., Kjesbu, O.S., Thorsen, A. 2003. Buoyancy of Atlantic cod larvae in relation to developmental stage and maternal influences. J. Plank. Res. 25(3), 291-307.

- Saborido-Rey, F., Morgan, M.J., Dominguez, R. 2004. Estimation of reproductive potential for Flemish Cap cod. NAFO SCR Documents. No. 04/61.

- Scott, B.E., Marteinsdottir, G., Begg, G.A., Wright, P., Kjesbu, O.S. 2005. Effects of population size/age structure, condition and temporal dynamics of spawning on reproductive output in Atlantic cod (Gadus morhua). Ecol Mod. 191, 383-415.

- Shulman, G. E., Love, R. M. 1999. The biochemical ecology of marine fishes. Adv. Mar. Biol. vol. 36. Ed. by A.J. Southward, P.A. Tayler and C.M. Young. Academic Press, London. $351 \mathrm{pp}$. 
Running title: New bioenergetic perspective of hake (Merluccius merluccius L.) reproductive ecology.

- Townsend, C.R., Winfield, I.J. 1985. The application of optimal foraging theory to feeding behaviour in fish. In: Tyler P. and P. Calow (Eds). Fish Energetics. New Perspectives. Ed Croom Helm London-Sydney, 67-98.

- Wootton, R.J. 1985. Energetics of reproduction. In: Tyler P. and P. Calow (Eds). Fish Energetics. New Perspectives. Ed Croom Helm London-Sydney, 231-254. 
Running title: New bioenergetic perspective of hake (Merluccius merluccius L.) reproductive ecology.

372

\section{Figure CAPTiOnS}

Figure 1.- Sampled areas of Galician Shelf in 2003 and 2004. Dotted line: European hake distribution area (Lloris et al., 2005).

Figure 2.- Linear regressions between gonadosomatic index (GSI) and a) hepatosomatic index (HSI; $\left.\mathrm{r}^{2}=0.0041, \mathrm{p}=0.276\right)$ and $\left.\mathrm{b}\right)$ condition factor $\left(\mathrm{K} ; \mathrm{r}^{2}=0.0492, \mathrm{p}<0.01\right)$. using various maternal attributes as predictors.

Figure 3.- Linear regression of energy density between tissues: a) gonad versus liver $\left(r^{2}=0.1740\right.$, $\mathrm{p}=0.002)$; and $\mathrm{b})$ gonad versus muscle $\left(\mathrm{r}^{2}=0.0823, \mathrm{p}=0.046\right)$.

Figure 4.- Observed versus predicted values obtained from the multiple regression of a) number of developing oocytes (NDO), $\mathrm{r}^{2}=0.273, \mathrm{p}<0.001$ and $\mathrm{b}$ ) batch fecundity $(\mathrm{BF}), \mathrm{r}^{2}=0.565, \mathrm{p}<0.001$; 
Running title: New bioenergetic perspective of hake (Merluccius merluccius L.) reproductive ecology.

387 Table I.- Monthly sampled females for each length class from 2003 to 2004.

\begin{tabular}{|c|c|c|c|c|c|c|c|c|c|c|c|c|c|c|c|c|c|c|c|c|c|c|c|}
\hline Length (cm) & \multicolumn{11}{|c|}{2003} & \multicolumn{11}{|c|}{2004} & Total \\
\hline$<45$ & 18 & 16 & 13 & 30 & 26 & 33 & 25 & 14 & 21 & 25 & 24 & 15 & 4 & 25 & 22 & 44 & 37 & 30 & & 1 & 17 & 23 & 463 \\
\hline $45-50$ & 1 & 16 & 20 & 11 & 9 & & 2 & 1 & 5 & 1 & 12 & 8 & 7 & 10 & 14 & 35 & 8 & 9 & 6 & 10 & 3 & 1 & 189 \\
\hline $50-55$ & 13 & 63 & 49 & 45 & 51 & 13 & 11 & 5 & 11 & 4 & 8 & 28 & 39 & 37 & 36 & 40 & 16 & 15 & 7 & 12 & 13 & & 516 \\
\hline$>60$ & 7 & 3 & 27 & 21 & 24 & 32 & 21 & 12 & 11 & 4 & 10 & 18 & 30 & 26 & 15 & 18 & 3 & 4 & 4 & 2 & 4 & & 296 \\
\hline Total & 57 & 125 & 144 & 147 & 183 & 115 & 94 & 56 & 68 & 40 & 63 & 110 & 117 & 145 & 116 & 161 & 74 & 68 & 25 & 37 & 43 & 24 & 2012 \\
\hline Total immature & 17 & 16 & 7 & 23 & 29 & 34 & 26 & 15 & 25 & 26 & 29 & 15 & 5 & 18 & 20 & 39 & 36 & 31 & & 2 & 18 & 23 & 454 \\
\hline Total mature & 40 & 109 & 137 & 124 & 154 & 81 & 68 & 41 & 43 & 14 & 34 & 95 & 112 & 127 & 96 & 122 & 38 & 37 & 25 & 35 & 25 & 1 & 1558 \\
\hline
\end{tabular}


Running title: New bioenergetic perspective of hake (Merluccius merluccius L.) reproductive ecology.

390 Table II.- Determination coefficient, correlation coefficient and p-values of relationships 391 established between the Number of Developing Oocytes (NDO) and Batch Fecundity (BF) and 392 maternal attributes.

\begin{tabular}{|c|c|c|c|c|}
\hline & & $\mathbf{r}^{2}$ & $\mathbf{r}$ & $\mathbf{p}$ \\
\hline \multirow{7}{*}{ NDO } & Length & 0.3884 & 0.6232 & $\leq 0.001$ \\
\hline & Gutted W & 0.4052 & 0.6366 & $\leq 0.001$ \\
\hline & HSI & 0.0140 & 0.1184 & $\leq 0.05$ \\
\hline & $\mathbf{K}$ & 0.0074 & -0.0863 & 0.0821 \\
\hline & Liver energy density & 0.0292 & -0.1710 & 0.2350 \\
\hline & Muscle energy density & 0.0109 & 0.1045 & 0.4703 \\
\hline & Total fish energy & 0.1358 & 0.3685 & $\leq 0.01$ \\
\hline \multirow{7}{*}{ BF } & Length & 0.4666 & 0.6831 & $\leq 0.001$ \\
\hline & Gutted W & 0.4668 & 0.6832 & $\leq 0.001$ \\
\hline & HSI & 0.0093 & 0.963 & 0.2183 \\
\hline & $\mathbf{K}$ & 0.0073 & -0.0855 & 0.2523 \\
\hline & Liver energy density & 0.4447 & -0.6668 & $\leq 0.05$ \\
\hline & Muscle energy density & 0.2984 & 0.5462 & 0.1281 \\
\hline & Total fish energy & 0.3091 & 0.5559 & 0.1201 \\
\hline
\end{tabular}



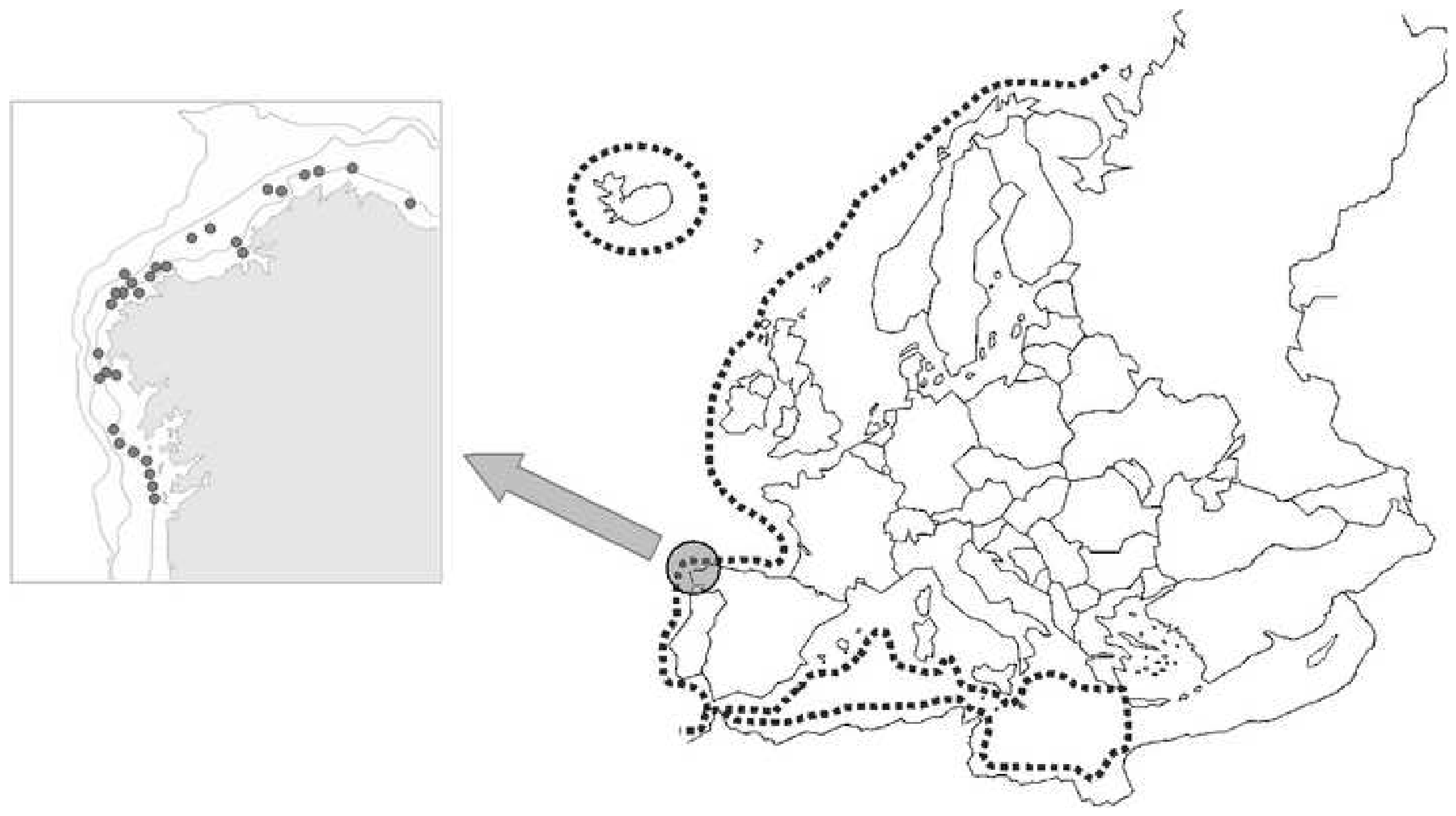
a)

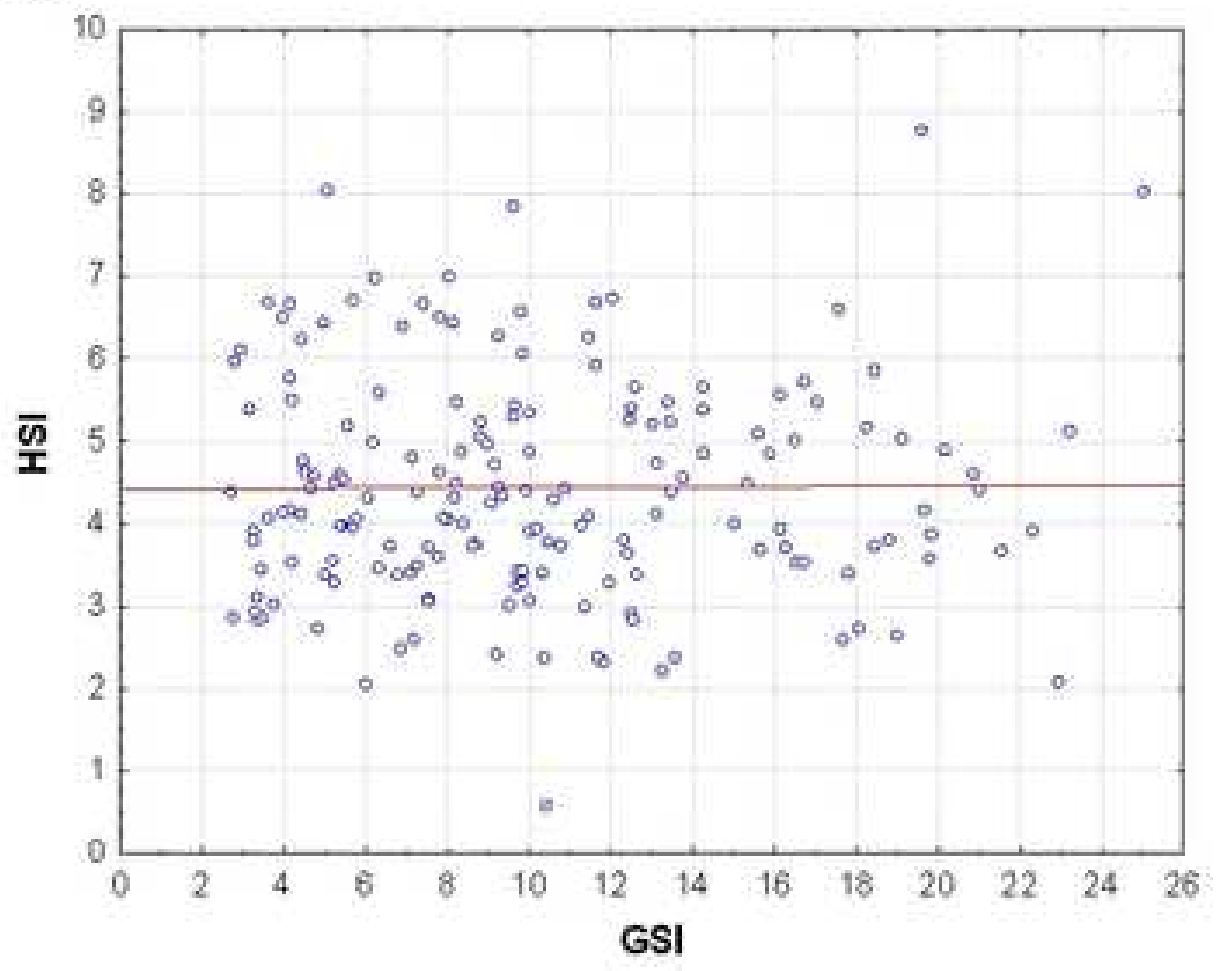

b)

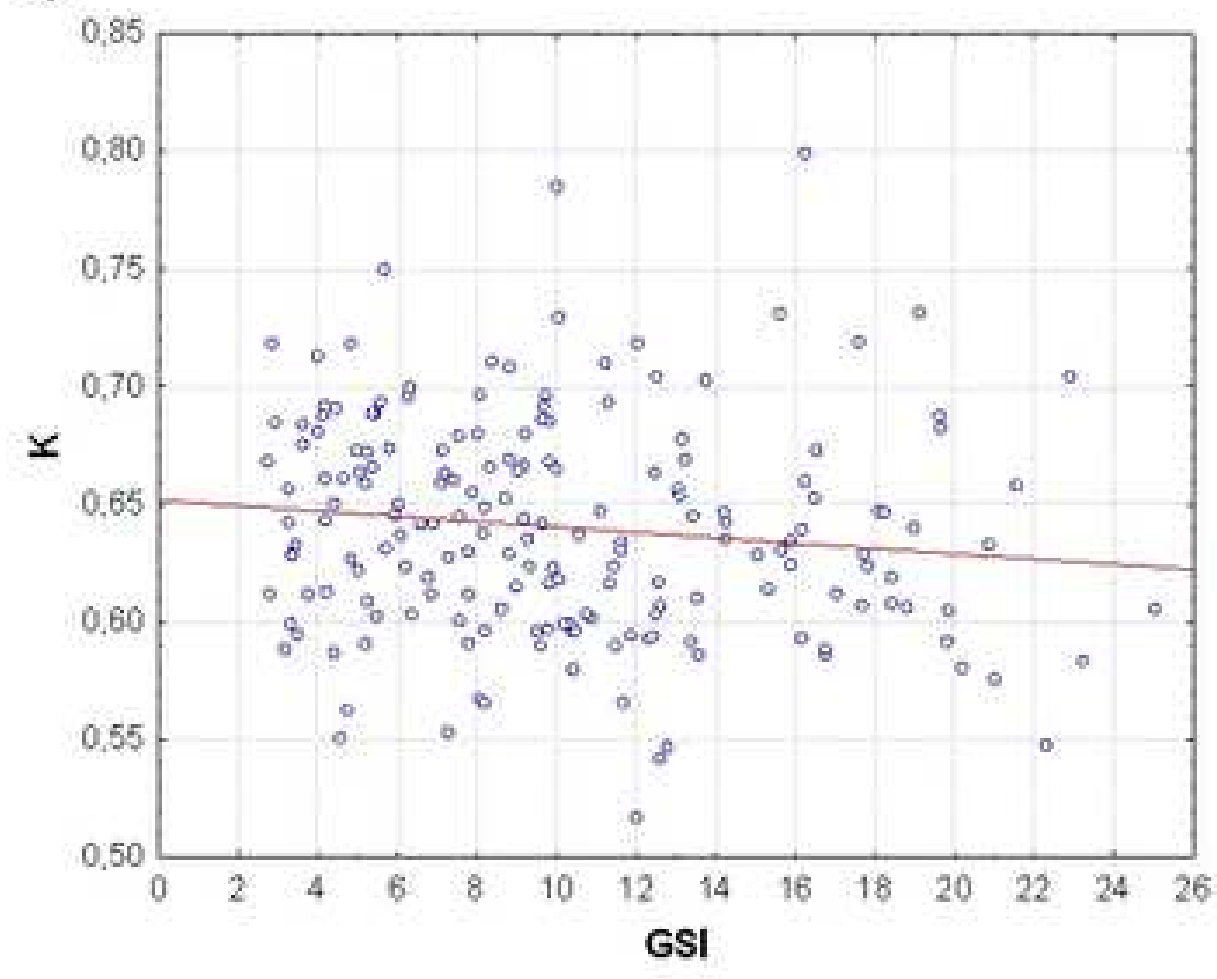


a)

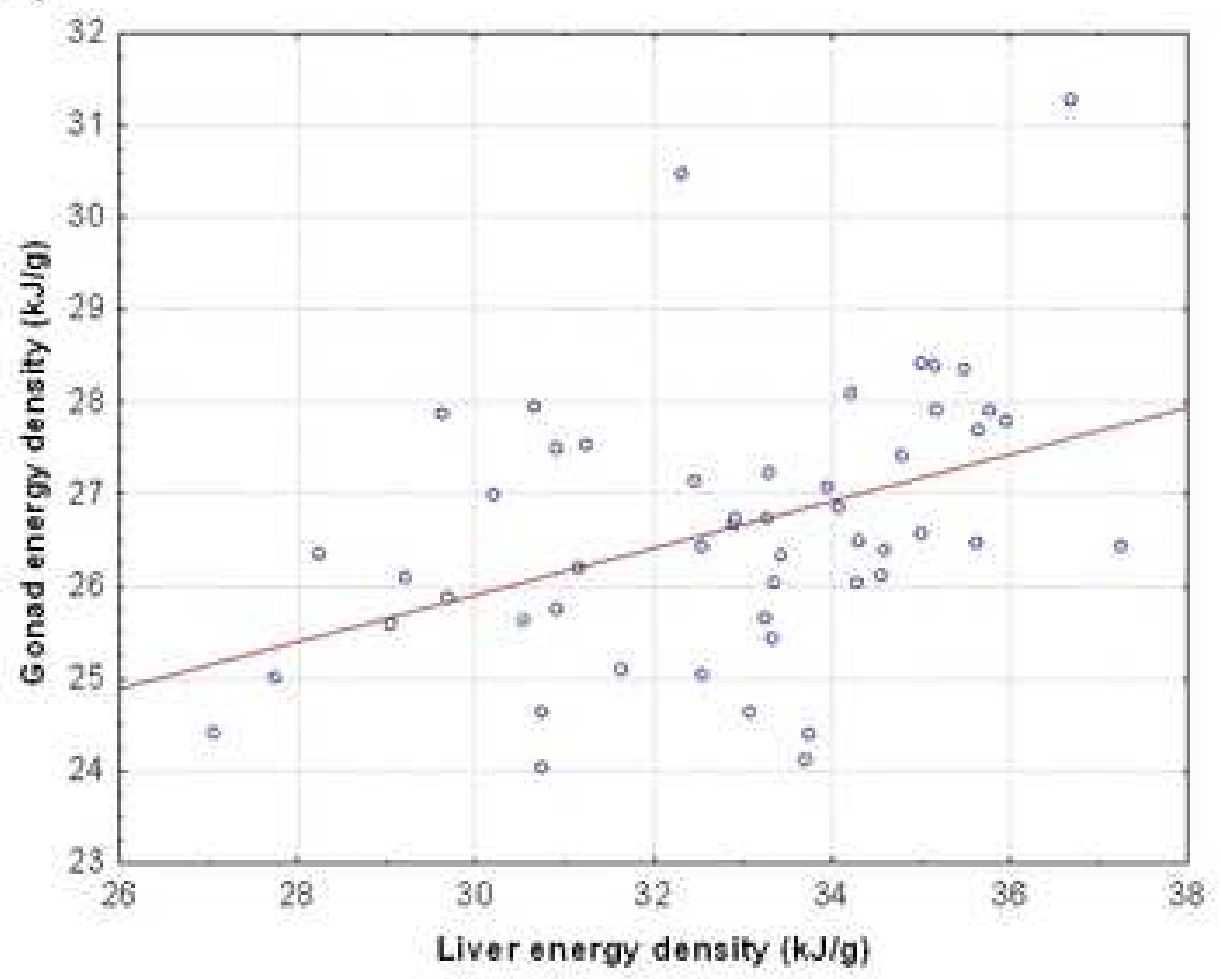

b)

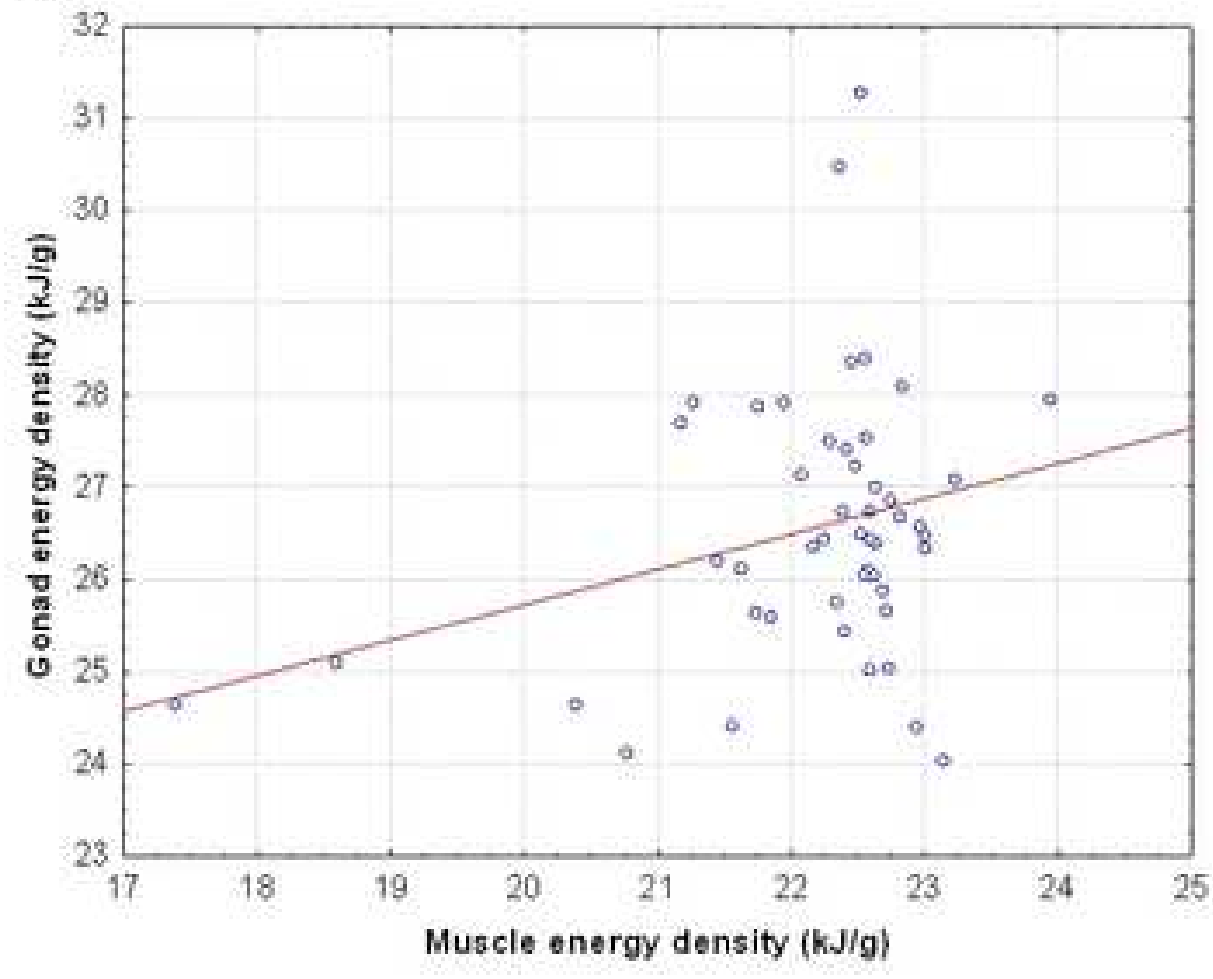


a)

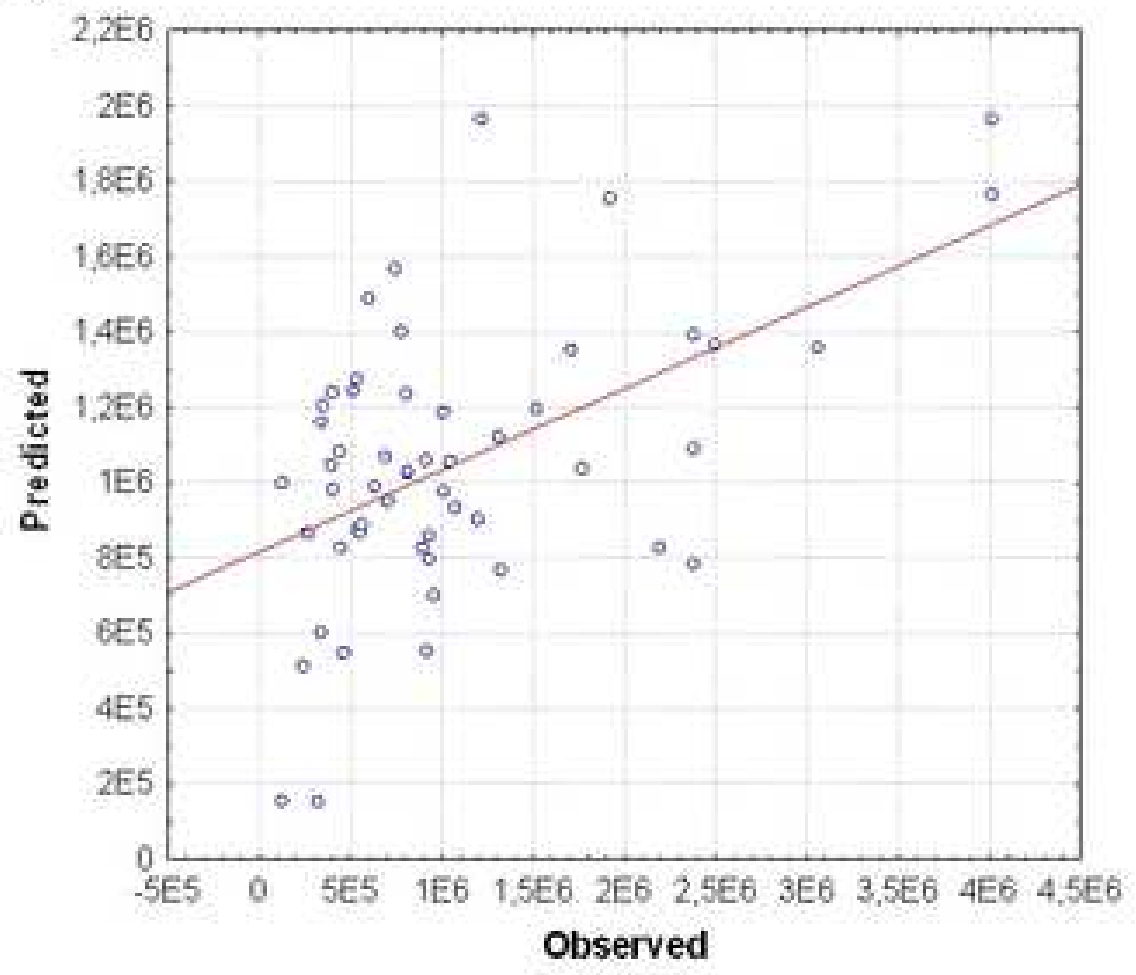

b)

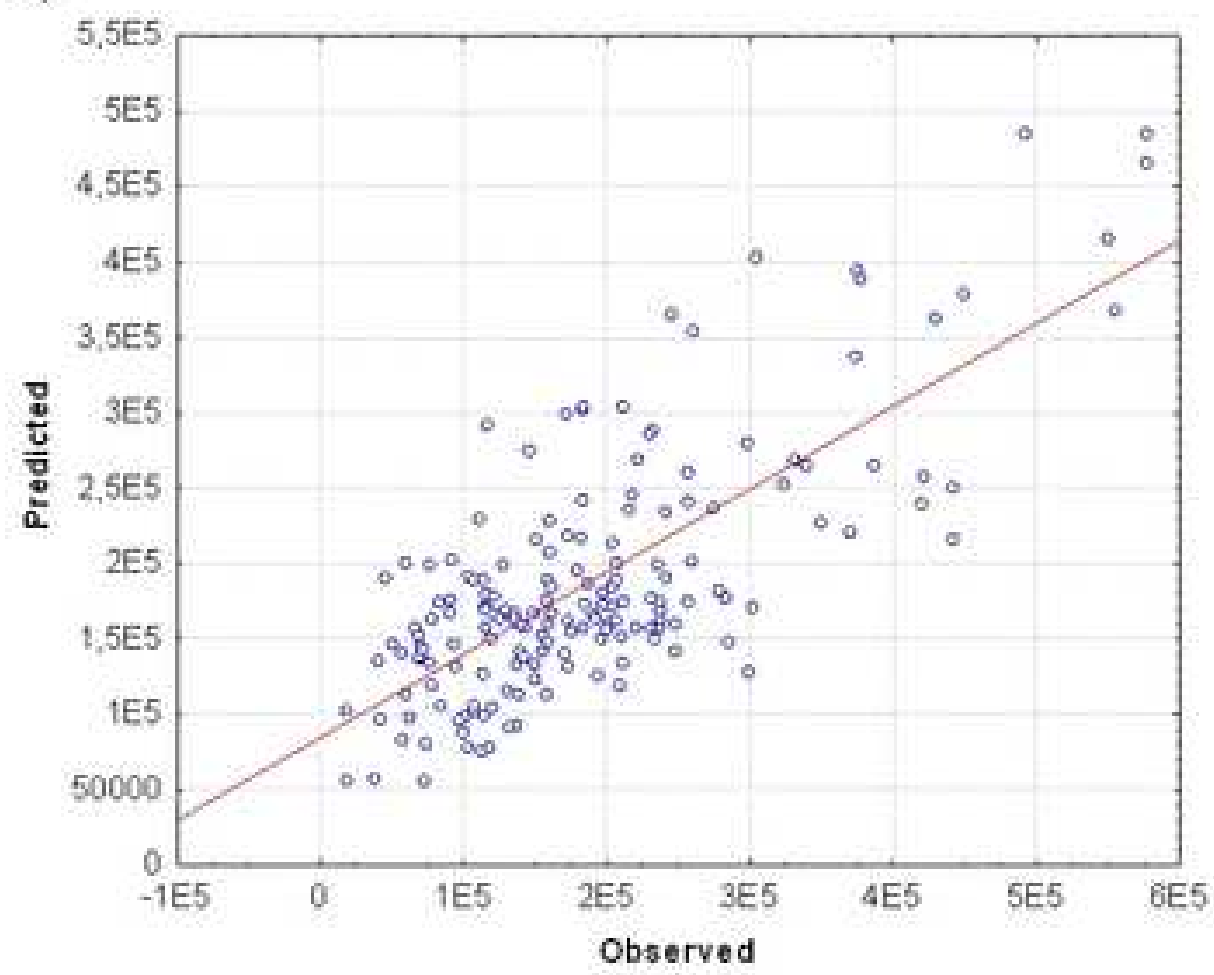

